
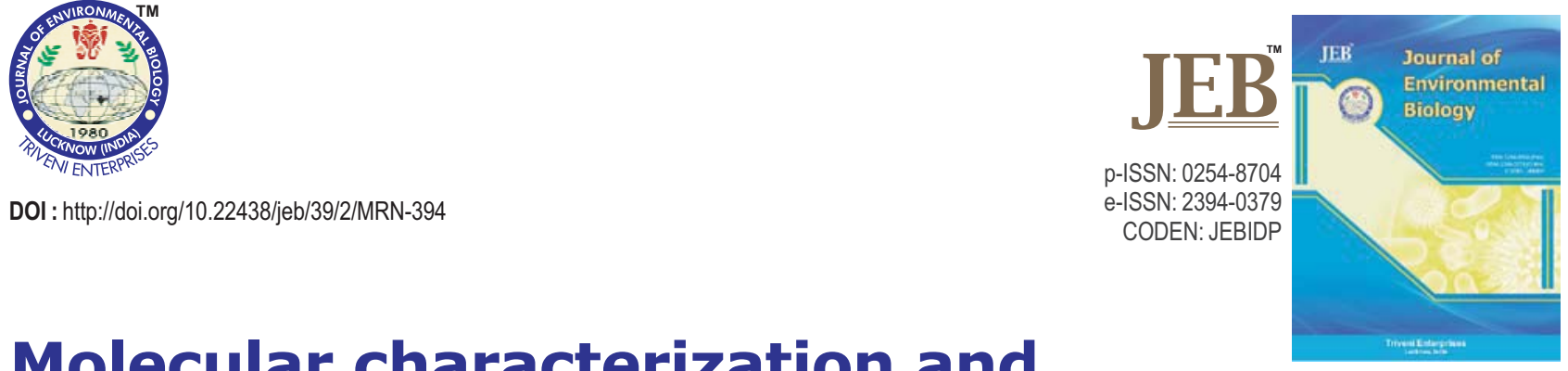

\title{
Molecular characterization and genetic diversity analysis of selected maize inbreds using SSR markers
}

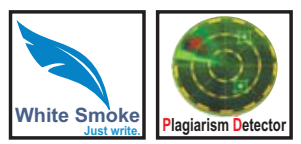

Authors Info

T. Sharma ${ }^{1,2 *}$, A. Kumar ${ }^{3,4}$, S. C. Dwivedi' and R. P. Vyas ${ }^{2}$

'School of Biosciences, Suresh Gyan Vihar University, Jaipur-302 017, India

${ }^{2}$ Department of Genetics and Plant Breeding, CSAUAT,

Kanpur-208 002, India

${ }^{3}$ UP Council of Agricultural

Research (UPCAR),

Lucknow- 226 010, India

${ }^{4}$ Department of Botany, Ch. Charan

Singh (PG) College, Heonra

(Saifai), Etawah- 206 002, India

*Corresponding Author Email : trivenidevsharma@gmail.com

Key words

Cluster analysis

Genetic diversity

Molecular characterization

Zea mays

SSR markers

\section{Publication Info}

Paper received : 30.06.2016

Revised received : 04.05.2017

Re-revised received : 15.06.2017

Accepted : 29.08.2017
Aim : The aim of the current study was to analyze the molecular diversity and genetic relationship among selected maize inbreds using SSR markers.

Methodology : Genomic DNA of individual inbreds was isolated by using the standard CTAB procedure (Doyle and Doyle, 1987) with some modifications. Thermal cycler was used to perform the polymerase chain reactions. 50ng of genomic DNA was used in $10 \mu$ l total volume with a final concentration of 10X Taq buffer, $\mathrm{MgCl}_{2}(50 \mu \mathrm{M})$, each primers $(10 \mu \mathrm{M})$, nucleotides $(2.5 \mathrm{mM})$ and $1 \mathrm{U}$ Red Taq DNA polymerase. Amplified PCR products were resolved by electrophoresis on horizontal gel (3.0\% Agarose gel) system using 1xTBE Buffer. The gels were photographed with CCD camera attached to a gel documentation system.

Results : In total, 191 alleles were detected which showed a range of 2 to 6 alleles per marker and an average value of 3.82 alleles per locus. Polymorphic information content (PIC) value showed a range of 0.050 (umc1069) to 0.817 (bnlg1823) with an average value of 0.585 indicating the efficiency of markers to study the level of polymorphism available in the maize inbred lines. The value of genetic similarity coefficients for the twenty maize inbreds based on $50 \mathrm{SSR}$ markers ranged from 0.51 to 0.74 . The maximum value of similarity coefficient was observed between CIM-127 vs CIM130 , whereas the minimum value of it was between TSK-7 vs TSK-2, TSK-41 vs TSK2. Cluster analyses, done using matrices of similarity in the NTSYS-pc software, classified studied inbred lines into four distinct clusters, Cluster A, B, C and D comprising of $5,5,5$ and 5 maize inbred lines, respectively.

Interpretation : In this study, PIC values indicated a good efficiency of markers for studying the polymorphism level available in studied inbred lines. High level of diversity among the inbreds detected with SSR markers indicated their suitability for further breeding programs.

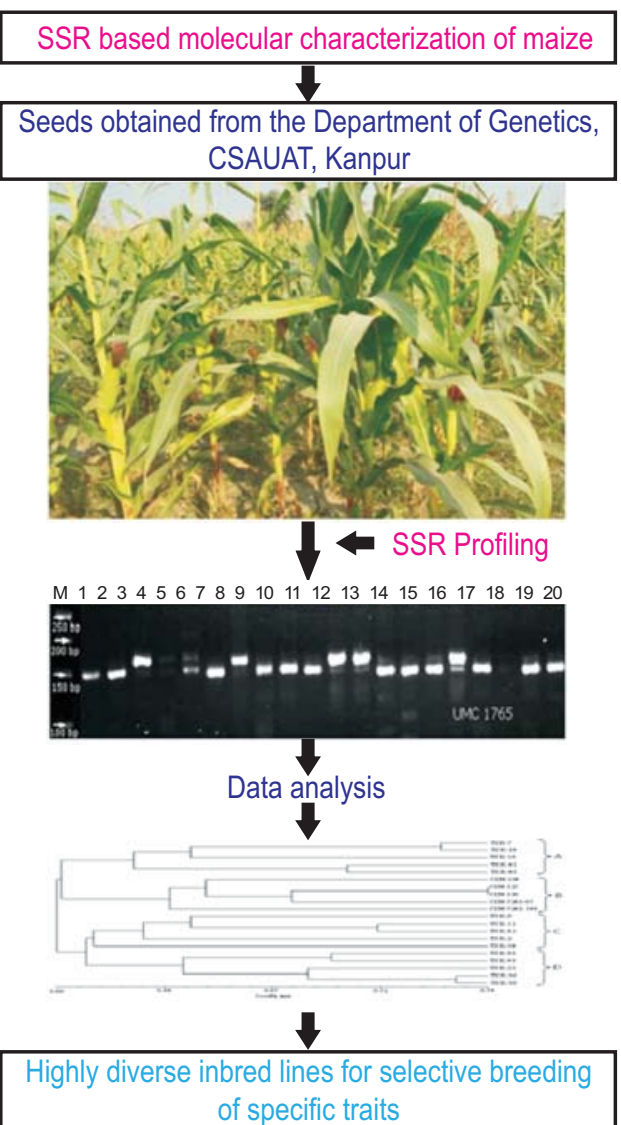




\section{Introduction}

Maize (Zea mays $L$.) is among the most important cereal crops in the world and a highly versatile and high potential crop having diploid chromosome number 20. Maize kernels contain 60 to $68 \%$ starch and 7 to $15 \%$ protein. It can be consumed as boiled, roasted vegetable by humans as well as a feed for livestock. In India, maize is the third most important cereal after rice and wheat that provides food, feed, fodder and serves as a source of raw material for the number of industrial products, viz. starch, oil, protein, food sweeteners, cosmetics, bio-fuel, etc. Genetic diversity in available germplasm plays a key role for future breeding progress. Study of genetic diversity is important in maize breeding program for the selection of suitable diverse parents to obtain heterotic hybrid as well as for germplasm characterization and conservation. Molecular markers being DNA based in nature produce more accurate and repeatable results compared to morphological data.

DNA-based molecular markers are a more precise and environment-independent way to assess the extent of genetic variation of a particular species. Among available DNA-based markers, Simple Sequence Repeat (SSR) markers are highly informative and easy detectable with PCR. They occur frequently in plant genomes, showing an extensive variation in different individuals and accessions (Sharma et al., 2010; Comertpay et al., 2012). Since SSR based molecular markers are co-dominant, multi-allelic, highly polymorphic and randomly distributed throughout the genome (Barcaccia et al., 2006), they are widely used for assessing maize genetic diversity (Nikolić et al., 2015; Salami et al., 2016). SSR markers have proved to be useful in various analysis like genetic diversity studies (Hidalgo et al., 2013), evolutionary studies (Zheng et al., 2013) and genetic map construction (Sa et al., 2012). These markers were frequently applied in different molecular genetic studies in maize for assessment of molecular diversity and molecular characterization of inbreds (Shehata et al., 2009; Suteum et al., 2014) and landraces (Ignjatovic-Micic et al., 2013; Molin et al., 2013). The objective of this study was genetic diversity and relationship analysis among 20 selected elite maize inbred lines using SSR markers.

\section{Materials and Methods}

Plant materials : Seeds of twenty inbred lines of maize were obtained from the Department of Genetics, C. S. Azad University of Agriculture and Technology, Kanpur (India) (Table- 1). The seeds were sown at experimental farm of CSA University of Agriculture and Technology, Kanpur. Healthy seeds of maize inbreds were sown in two replicates using standard agronomical practices. Fresh young leaves of maize were collected to isolate genomic DNA.

Genomic DNA extraction : Genomic DNA of individual genotypes was isolated using the standard CTAB (Doyle and
Table 1: List of inbred lines of maize

\begin{tabular}{ll}
\hline Inbred line & Inbred line \\
\hline TSK-7 & TSK-41 \\
TSK-9 & TSK-43 \\
TSK-11 & TSK-45 \\
TSK-14 & TSK-48 \\
TSK-16 & TSK-49 \\
TSK-22 & CIM-7242-67 \\
TSK-33 & CIM-7242-149 \\
TSK-34 & CIM-130 \\
TSK-36 & CIM-127 \\
TSK-39 & CIM-104 \\
\hline
\end{tabular}

Doyle, 1987) with some modifications. About $5 \mathrm{~g}$ leaf materials was collected, frozen and was crushed to a fine powder adding in a pestle and mortar. The powder was transferred to polypropylene centrifuge tubes $(50 \mathrm{~m})$ containing $20 \mathrm{ml}$ pre-warmed extraction buffer (100 mM Tris, $20 \mathrm{mM}$ EDTA, $1.4 \mathrm{M} \mathrm{NaCl}$ and 2\% CTAB) which was maintained at $65^{\circ} \mathrm{C}$. The content was mixed vigorously. The suspension was incubated $\left(65^{\circ} \mathrm{C}\right)$ for one hour with intermittent mixing. Chloroform-isoamyl alcohol ( 0.6 volume) was added and mixed gently for $5 \mathrm{~min}$ by inversion. The content was centrifuged at 15,000 rpm for $10 \mathrm{~min}$ at room temperature. Aqueous phase was transferred to fresh centrifuge tubes with a wide bore pipette and $2 / 3$ volume of isopropanol was added to it. The content was mixed by quick gentle inversion. The precipitated DNA was spooled out using a disposable pipette tip and washed two times with $70 \%$ ethanol. The pellet was dried under vacuum and dissolved in minimum volume of TE buffer and stored after that. To remove RNA, DNA was treated with $50 \mu \mathrm{g}$ RNAse for one hour at $37^{\circ} \mathrm{C}$ and stored at $4^{\circ} \mathrm{C}$ until further use.

SSR markers, PCR Amplification and gel electrophoresis : 50 SSR primers were used to analyze genomic DNA of twenty inbreds. The primer sequences were obtained from Integrated DNA Technology, USA. The polymerase chain reactions were performed using thermal cycler (Long Gene). $50 \mathrm{ng}$ of genomic DNA was used in $10 \mu$ total volume with a final concentration of 10X Taq buffer, $\mathrm{MgCl}_{2}(50 \mu \mathrm{M})$, primers $(10 \mu \mathrm{M}), 2.5 \mathrm{mM}$ of each nucleotide and $1 \mathrm{U}$ Red Taq DNA polymerase (Bangalore GeNei, India).

The PCR was programmed for the following steps: initial denaturation at $94^{\circ} \mathrm{C}$ for 4 min and during subsequent 35 cycles, each with denaturation at $94^{\circ} \mathrm{C}$ for $1 \mathrm{~min}$, primer annealing $\left(58^{\circ} \mathrm{C}\right)$ for $1 \mathrm{~min}$ and primer extension at $72^{\circ} \mathrm{C}$ for $2 \mathrm{~min}$. The extension step was performed at $72^{\circ} \mathrm{C}$ for $7 \mathrm{~min}$. Reactions were stopped with 2.0 $\mu$ l of loading dye (6x loading dye).

Amplified products were resolved by electrophoresis on horizontal gel (3.0\% Agarose) system using 1x TBE Buffer. The gel was prepared by melting agarose and $0.1 \mathrm{gml}^{-1}$ Ethidium Bromide ( $5 \mu \mathrm{l} \mathrm{EtBr} \mathrm{in} 100 \mathrm{ml}$ of Agarose gel) was added. The gels were run at 50 volt for $3 \mathrm{hrs}$. 


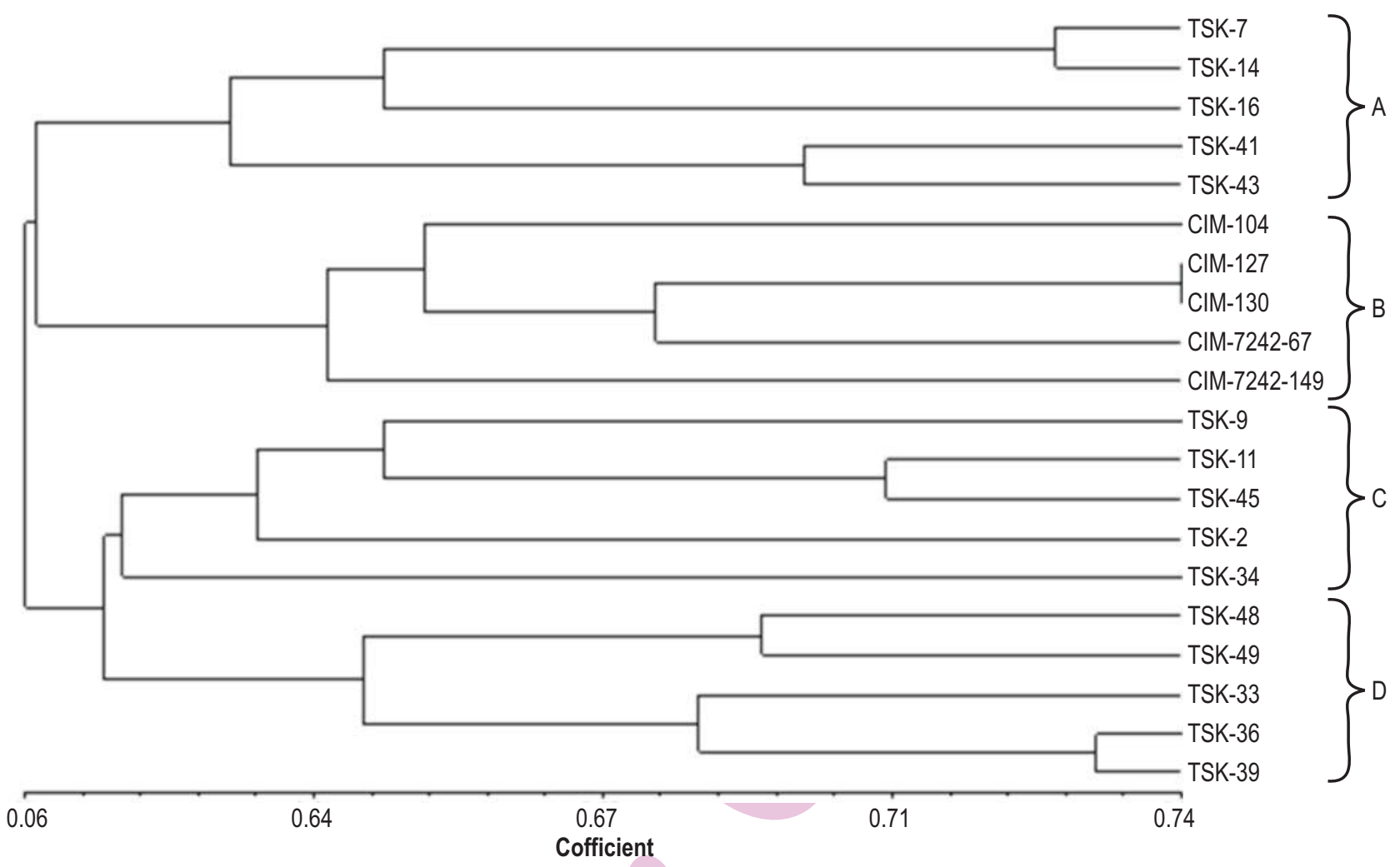

Fig. 1 : UPGMA based cluster analysis of 20 maize inbred lines using SSR primers

Data scoring and analysis : The gel was photographed using CCD camera attached to a gel documentation system with the Quantity One software (Alpha Innotech). Scoring was done manually for each of the gel sections allele was determined base on the positions of the bands. Band pattern for each marker was recorded for each genotype by assigning a letter to each band. Alleles were numbered as ' $a_{1}$ ', ' $a_{2}$ ' etc based on their size. In the data matrix, presence of a band was represented by ' 1 ' and absence by ' 0 '. The marker data were entered directly into an excel spreadsheet with the microsatellite allele under rows and genotype under columns.

$\mathrm{PIC}$ is synonymous with the term "gene diversity" as described by Weir (1996). The PIC valve ranging from ' 0 ' to ' 11 ' is an indication of discriminatory power of marker where ' 0 ' denotes monomorphic nature of the marker and ' 1 ' describe it to be highly discriminative with many alleles in equal frequency. In the present investigation, SSR data was used for cluster analysis. Genetic similarity based on SSR data can be calculated for all possible pairs of genotype using various coefficients. Jaccard's coefficients $(J)$, calculated as $J=N_{i j} /\left(N_{i j}+N_{i}+N_{j}\right)$ was used to estimate genetic similarities, where $\mathrm{N}_{\mathrm{ij}}$ represents the number of bands present in the both individual, $\mathrm{N}_{\mathrm{i}}$ depicts the total number of bands in the individual $i$ and $\mathrm{N}_{\mathrm{j}}$ is the total number of bands in the individual $j$. The similarity matrix was worked out using
NTSYS-pc version 2.2 to produce an agglomerative hierarchical classification (Rohlf, 2000), by employing UPGMA (Unweighted Paired Group method using Arithmetic Mean) method with average linkage (Sneath and Sokal, 1973).

\section{Results and Discussion}

Simple sequence repeat markers (SSR) were used to assess the genetic divergence among 20 inbreds of maize (Zea mays L.). Based on the specificity of genotype of a plant, a particular DNA profile can be ascribed to a particular plant. Analysis of the distribution of the SSR alleles across the maize lines revealed that almost all the alleles were shared by Zea mays.. Analysis of PIC values revealed that all of the SSR markers studied were found to be highly polymorphic. The PIC value ranged from 0.050 to 0.817 with an average of 0.585 among the studied primers. All these primers were found to be polymorphic (Table 2). A total of 191 alleles were recorded at 50 SSR loci with an average of 3.82 alleles per locus with their distribution as 2 alleles in 12 primers, 3 alleles in 13 primers, 4 alleles in 6 primers, 5 alleles in 10 primers and 6 alleles in 9 primers. Maximum number of alleles ( 6 alleles) were observed in primers viz; bnlg1823, umc1136, umc2227, umc1015, bnlg2235, umc2383, bnlg1194, umc1705, umc1353 and minimum number of alleles (2 alleles) were observed in primers viz; umc2069, 
Table2 : PIC values of SSR loci across 20 inbred lines of maize

\begin{tabular}{|c|c|c|c|c|c|c|}
\hline Primers & Alleles & $\begin{array}{l}\text { No. of } \\
\text { accessions } \\
\text { sharing alleles }\end{array}$ & $\begin{array}{l}\text { Frequency of } \\
\text { SSR alleles }\end{array}$ & $\begin{array}{l}\text { No. of accessions } \\
\text { showing } \\
\text { amplification }\end{array}$ & $\begin{array}{l}\text { No. of } \\
\text { alleles }\end{array}$ & PIC \\
\hline \multirow{5}{*}{ umc1078 } & $a_{1}$ & 8 & 0.228 & 19 & 5 & 0.771 \\
\hline & $a_{2}$ & 10 & 0.298 & & & \\
\hline & $a_{3}$ & 8 & 0.210 & & & \\
\hline & $a_{4}$ & 2 & 0.052 & & & \\
\hline & $a_{5}$ & 9 & 0.210 & & & \\
\hline \multirow[t]{6}{*}{ bnlg1823 } & $a_{1}$ & 4 & 0.205 & 17 & 6 & 0.817 \\
\hline & $a_{2}$ & 5 & 0.205 & & & \\
\hline & $a_{3}$ & 3 & 0.088 & & & \\
\hline & $\mathrm{a}_{4}$ & 5 & 0.176 & & & \\
\hline & $a_{5}$ & 5 & 0.235 & & & \\
\hline & $a_{6}$ & 2 & 0.088 & & & \\
\hline \multirow[t]{4}{*}{ umc2120 } & $a_{1}$ & 1 & 0.017 & 20 & 4 & 0.504 \\
\hline & $\mathrm{a}_{2}$ & 5 & 0.092 & & & \\
\hline & $a_{3}$ & 18 & 0.658 & & & \\
\hline & $a_{4}$ & 9 & 0.233 & & & \\
\hline \multirow[t]{6}{*}{ umc1136 } & $a_{1}$ & 13 & 0.403 & 19 & 6 & 0.751 \\
\hline & $a_{2}$ & 6 & 0.149 & & & \\
\hline & $a_{3}$ & 2 & 0.044 & & & \\
\hline & $\mathrm{a}_{4}$ & 3 & 0.105 & & & \\
\hline & $a_{5}$ & 9 & 0.219 & & & \\
\hline & $a_{6}$ & 3 & 0.078 & & & \\
\hline \multirow[t]{4}{*}{ umc1746 } & $a_{1}$ & 12 & 0.333 & 20 & 4 & 0.738 \\
\hline & $a_{2}$ & 7 & 0.233 & & & \\
\hline & $a_{3}$ & 6 & 0.167 & & & \\
\hline & $a_{4}$ & 8 & 0.267 & & & \\
\hline \multirow[t]{6}{*}{ umc2227 } & $a_{1}$ & 3 & 0.037 & 20 & 6 & 0.774 \\
\hline & $a_{2}$ & 7 & 0.096 & & & \\
\hline & $a_{3}$ & 9 & 0.133 & & & \\
\hline & $\mathrm{a}_{4}$ & 9 & 0.125 & & & \\
\hline & $a_{5}$ & 20 & 0.304 & & & \\
\hline & $a_{6}$ & 20 & 0.304 & & & \\
\hline \multirow[t]{6}{*}{ umc1015 } & $a_{1}$ & 5 & 0.117 & 20 & 6 & 0.795 \\
\hline & $a_{2}$ & 9 & 0.187 & & & \\
\hline & $a_{3}$ & 6 & 0.133 & & & \\
\hline & $\mathrm{a}_{4}$ & 8 & 0.154 & & & \\
\hline & $a_{5}$ & 4 & 0.071 & & & \\
\hline & $a_{6}$ & 14 & 0.337 & & & \\
\hline \multirow[t]{6}{*}{ bnlg2235 } & $a_{1}$ & 5 & 0.101 & 19 & 6 & 0.804 \\
\hline & $a_{2}$ & 11 & 0.228 & & & \\
\hline & $a_{3}$ & 8 & 0.232 & & & \\
\hline & $\mathrm{a}_{4}$ & 4 & 0.078 & & & \\
\hline & $a_{5}$ & 5 & 0.101 & & & \\
\hline & $a_{6}$ & 10 & 0.258 & & & \\
\hline \multirow[t]{4}{*}{ bnlg1847 } & $a_{1}$ & 6 & 0.202 & 19 & 4 & 0.649 \\
\hline & $a_{2}$ & 8 & 0.307 & & & \\
\hline & $a_{3}$ & 11 & 0.465 & & & \\
\hline & $a_{4}$ & 1 & 0.026 & & & \\
\hline \multirow[t]{5}{*}{ phi109275 } & $a_{1}$ & 5 & 0.092 & 20 & 5 & 0.745 \\
\hline & $a_{2}$ & 4 & 0.083 & & & \\
\hline & $a_{3}$ & 10 & 0.192 & & & \\
\hline & $\mathrm{a}_{4}$ & 8 & 0.267 & & & \\
\hline & $a_{5}$ & 11 & 0.367 & & & \\
\hline
\end{tabular}




\begin{tabular}{|c|c|c|c|c|c|c|}
\hline \multirow[t]{5}{*}{ umc2204 } & $a_{1}$ & 6 & 0.158 & 20 & 5 & 0.744 \\
\hline & $\mathrm{a}_{2}$ & 4 & 0.108 & & & \\
\hline & $a_{3}$ & 6 & 0.158 & & & \\
\hline & $\mathrm{a}_{4}$ & 10 & 0.417 & & & \\
\hline & $a_{5}$ & 5 & 0.158 & & & \\
\hline \multirow[t]{6}{*}{ umc2383 } & $a_{1}$ & 3 & 0.050 & 20 & 6 & 0.760 \\
\hline & $\mathrm{a}_{2}$ & 8 & 0.167 & & & \\
\hline & $a_{3}$ & 7 & 0.125 & & & \\
\hline & $\mathrm{a}_{4}$ & 5 & 0.125 & & & \\
\hline & $a_{5}$ & 15 & 0.408 & & & \\
\hline & $a_{6}$ & 7 & 0.125 & & & \\
\hline \multirow[t]{5}{*}{ bnlg1831 } & $a_{1}$ & 3 & 0.050 & 20 & 5 & 0.684 \\
\hline & $a_{2}$ & 5 & 0.092 & & & \\
\hline & $a_{3}$ & 13 & 0.308 & & & \\
\hline & $\mathrm{a}_{4}$ & 14 & 0.450 & & & \\
\hline & $a_{5}$ & 3 & 0.100 & & & \\
\hline \multirow[t]{4}{*}{ bnlg1367 } & $a_{1}$ & 3 & 0.075 & 20 & 4 & 0.628 \\
\hline & $a_{2}$ & 2 & 0.075 & & & \\
\hline & $a_{3}$ & 9 & 0.400 & & & \\
\hline & $a_{4}$ & 11 & 0.450 & $\gamma$ & & \\
\hline \multirow[t]{6}{*}{ bnlg1194 } & $a_{1}$ & 2 & 0.031 & 19 & 6 & 0.783 \\
\hline & $a_{2}$ & 10 & 0.337 & & & \\
\hline & $a_{3}$ & 5 & 0.110 & & & \\
\hline & $\mathrm{a}_{4}$ & 5 & 0.140 & & & \\
\hline & $a_{5}$ & 6 & 0.188 & & & \\
\hline & $a_{6}$ & 6 & 0.193 & & & \\
\hline \multirow[t]{3}{*}{ phi059 } & $a_{1}$ & 4 & 0.096 & 19 & 3 & 0.506 \\
\hline & $a_{2}$ & 17 & 0.649 & & & \\
\hline & $a_{3}$ & 8 & 0.254 & & & \\
\hline \multirow[t]{6}{*}{ umc1705 } & $a_{1}$ & 4 & 0.092 & 20 & 6 & 0.607 \\
\hline & $a_{2}$ & 7 & 0.146 & & & \\
\hline & $a_{3}$ & 4 & 0.079 & & & \\
\hline & $a_{4}$ & 20 & 0.596 & & & \\
\hline & $a_{5}$ & 2 & 0.050 & & & \\
\hline & $a_{6}$ & 2 & 0.037 & & & \\
\hline \multirow[t]{3}{*}{ umc1907 } & $a_{1}$ & 4 & 0.139 & 18 & 3 & 0.440 \\
\hline & $a_{2}$ & 3 & 0.139 & & & \\
\hline & $a_{3}$ & 15 & 0.723 & & & \\
\hline \multirow[t]{5}{*}{ bnlg1043 } & $a_{1}$ & 10 & 0.315 & 19 & 5 & 0.742 \\
\hline & $a_{2}$ & 4 & 0.114 & & & \\
\hline & $a_{3}$ & 7 & 0.315 & & & \\
\hline & $a_{4}$ & 2 & 0.035 & & & \\
\hline & $a_{5}$ & 6 & 0.219 & & & \\
\hline \multirow[t]{2}{*}{ umc2069 } & $\mathrm{a}_{1}$ & 4 & 0.117 & 17 & 2 & 0.209 \\
\hline & $a_{2}$ & 17 & 0.882 & & & \\
\hline \multirow[t]{4}{*}{ umc1141 } & $a_{1}$ & 14 & 0.360 & 19 & 4 & 0.693 \\
\hline & $a_{2}$ & 2 & 0.043 & & & \\
\hline & $a_{3}$ & 14 & 0.394 & & & \\
\hline & $\mathrm{a}_{4}$ & 10 & 0.149 & & & \\
\hline \multirow[t]{6}{*}{ umc1353 } & $a_{1}$ & 2 & 0.039 & 19 & 6 & 0.679 \\
\hline & $a_{2}$ & 3 & 0.065 & & & \\
\hline & $\mathrm{a}_{3}$ & 14 & 0.360 & & & \\
\hline & $\mathrm{a}_{4}$ & 13 & 0.425 & & & \\
\hline & $a_{5}$ & 4 & 0.083 & & & \\
\hline & $a_{6}$ & 2 & 0.026 & & & \\
\hline
\end{tabular}




\begin{tabular}{|c|c|c|c|c|c|c|}
\hline \multirow[t]{5}{*}{ bnlg1346 } & $a_{1}$ & 3 & 0.095 & 14 & 5 & 0.772 \\
\hline & $a_{2}$ & 4 & 0.155 & & & \\
\hline & $a_{3}$ & 8 & 0.333 & & & \\
\hline & $\mathrm{a}_{4}$ & 4 & 0.202 & & & \\
\hline & $a_{5}$ & 5 & 0.214 & & & \\
\hline \multirow{3}{*}{ umc1844 } & $a_{1}$ & 12 & 0.272 & 19 & 3 & 0.661 \\
\hline & $a_{2}$ & 14 & 0.324 & & & \\
\hline & $a_{3}$ & 15 & 0.403 & & & \\
\hline \multirow[t]{4}{*}{ bnlg1070 } & $a_{1}$ & 6 & 0.214 & 14 & 4 & 0.735 \\
\hline & $a_{2}$ & 9 & 0.357 & & & \\
\hline & $a_{3}$ & 6 & 0.178 & & & \\
\hline & $\mathrm{a}_{4}$ & 6 & 0.250 & & & \\
\hline \multirow[t]{3}{*}{ bnlg1017 } & $a_{1}$ & 2 & 0.037 & 18 & 3 & 0.535 \\
\hline & $a_{2}$ & 14 & 0.509 & & & \\
\hline & $a_{3}$ & 13 & 0.453 & & & \\
\hline \multirow[t]{3}{*}{ bnlg1117 } & $a_{1}$ & 8 & 0.267 & 15 & 3 & 0.605 \\
\hline & $a_{2}$ & 3 & 0.200 & & & \\
\hline & $a_{3}$ & 12 & 0.533 & & & \\
\hline \multirow[t]{3}{*}{ phi114 } & $a_{1}$ & 15 & 0.394 & 19 & 3 & 0.584 \\
\hline & $a_{2}$ & 17 & 0.500 & & & \\
\hline & $a_{3}$ & 5 & 0.105 & & & \\
\hline \multirow[t]{3}{*}{ umc1002 } & $a_{1}$ & 3 & 0.138 & 18 & 3 & 0.449 \\
\hline & $a_{2}$ & 4 & 0.194 & & & \\
\hline & $a_{3}$ & 13 & 0.667 & & & \\
\hline \multirow[t]{2}{*}{ umc1055 } & $a_{1}$ & 3 & 0.156 & 16 & 2 & 0.266 \\
\hline & $a_{2}$ & 14 & 0.843 & & & \\
\hline \multirow[t]{2}{*}{ umc1254 } & $a_{1}$ & 7 & 0.368 & 19 & 2 & 0.467 \\
\hline & $a_{2}$ & 12 & 0.631 & & & \\
\hline \multirow[t]{3}{*}{ umc1276 } & $a_{1}$ & 7 & 0.225 & 20 & 3 & 0.648 \\
\hline & $\mathrm{a}_{2}$ & 11 & 0.425 & & & \\
\hline & $a_{3}$ & 12 & 0.350 & & & \\
\hline \multirow[t]{5}{*}{ umc1297 } & $a_{1}$ & 2 & 0.069 & 18 & 5 & 0.730 \\
\hline & $\mathrm{a}_{2}$ & 9 & 0.194 & & & \\
\hline & $a_{3}$ & 9 & 0.194 & & & \\
\hline & $\mathrm{a}_{4}$ & 5 & 0.125 & & & \\
\hline & $a_{5}$ & 9 & 0.421 & & & \\
\hline \multirow[t]{3}{*}{ umc1350 } & $a_{1}$ & 6 & 0.357 & 14 & 3 & 0.645 \\
\hline & $a_{2}$ & 5 & 0.214 & & & \\
\hline & $a_{3}$ & 9 & 0.428 & & & \\
\hline \multirow[t]{2}{*}{ umc1765 } & $a_{1}$ & 7 & 0.263 & 19 & 2 & 0.390 \\
\hline & $a_{2}$ & 16 & 0.736 & & & \\
\hline \multirow[t]{3}{*}{ umc1655 } & $a_{1}$ & 15 & 0.442 & 20 & 3 & 0.612 \\
\hline & $a_{2}$ & 4 & 0.142 & & & \\
\hline & $a_{3}$ & 14 & 0.417 & & & \\
\hline \multirow[t]{3}{*}{ umc1766 } & $a_{1}$ & 7 & 0.340 & 18 & 3 & 0.655 \\
\hline & $a_{2}$ & 7 & 0.340 & & & \\
\hline & $a_{3}$ & 7 & 0.340 & & & \\
\hline \multirow[t]{2}{*}{ umc1858 } & $a_{1}$ & 5 & 0.187 & 16 & 2 & 0.307 \\
\hline & $a_{2}$ & 15 & 0.812 & & & \\
\hline \multirow[t]{2}{*}{ umc1871 } & $a_{1}$ & 12 & 0.445 & 18 & 2 & 0.493 \\
\hline & $\mathrm{a}_{2}$ & 14 & 0.556 & & & \\
\hline \multirow[t]{2}{*}{ bnlg1189 } & $a_{1}$ & 10 & 0.468 & 16 & 2 & 0.500 \\
\hline & $a_{2}$ & 11 & 0.531 & & & \\
\hline umc2071 & $a_{1}$ & 9 & 0.464 & 14 & 2 & 0.499 \\
\hline & $a_{2}$ & 10 & 0.535 & & & \\
\hline
\end{tabular}




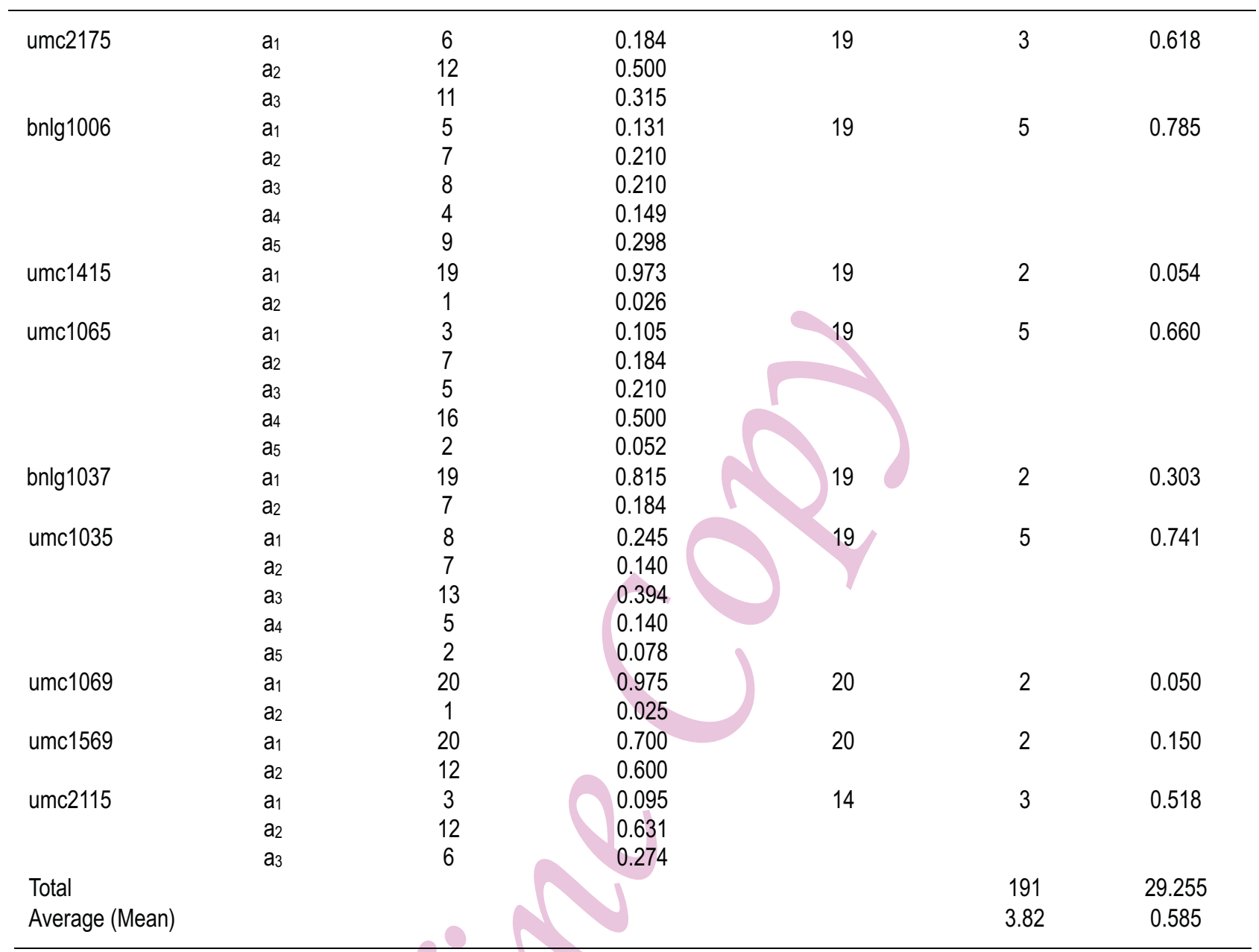

umc1055, umc1254, umc1765, umc1858, umc1871, bnlg1189, umc2071, umc1415, bnlg1037, umc1069, umc1569. Summarized data regarding the allele number, allele frequencies and allele distribution for various primers studied on 20 maize inbred lines are provided in Table2.

PIC values were estimated for different SSR loci based on the allele frequencies. Range of PIC value was found to be from 0.050 to 0.817 with an average of 0.585 . On the basis of alleles, number of sharing alleles and their frequencies, the highest value of PIC (0.817) was found for the primer bnlg1823 because of well distributed presence of six alleles across the inbred lines followed by 0.804 for primer bnlg2235, 0.795 in primer umc1015, 0.785 with primer bnlg1006, 0.783 for primer bnlg1194 and 0.774 with primer umc2227. The lowest value of PIC (0.050) was shown by primer umc1069. The reason for low PIC value may be the poor distribution of alleles in the genome. Various workers have already reported similar results in maize (Jambrovic et al., 2008; Shehata et al., 2009; Suteu et al., 2013; Nikolić et al., 2015). Lu and Bernardo (2001) reported an average of 4.9 alleles for 83 SSR loci in 40 U.S. maize inbred lines. Similarly, Senior et al., (1998) reported an average of 5.0 alleles per locus. Warburton et al., (2002) amplified 416 bands in CIMMYT maize inbred lines, with an average number of 4.9 and a range of 2 to 14 alleles per locus among the 85 SSR loci studied. On the other hand, Liu et al., (2003) reported average 21.7 alleles per locus at 94 SSR loci studied among 260 US inbreds.

However, in the present study low and high alleles showed polymorphism level on the basis of highest and lowestamplification. On the basis of PIC values, the genotypes sharing alleles and distribution of alleles in the genome can be identified. PIC values ranged from 0.050 to 0.817 with an average of 0.585 indicates a considerable efficiency of markers for studying the polymorphism level in maize inbred lines. SSRs undoubtedly represent a useful molecular tool that, either alone or in combination with additional approaches defining the internal genetic relationships among genotypes of large germplasm collections. The robustness of the systems of identification based on SSRs has been progressively implemented by augmenting the number of SSRs that are concomitantly used rather than increasing the length of their core, repeated unit (Gavazzi etal., 2016).

Range of genetic similarity coefficients for twenty maize inbred lines based on 50 SSR markers was from 0.51 to 0.74 . The 
highest similarity coefficient value (74\%) was observed between CIM-127 vs CIM-130 and the lowest similarity coefficient value (51\%) was observed between TSK-7 vs TSK-2. For TSK-41 vs TSK-2, it was $51 \%$. The resulting dendrogram classified studied inbred lines into 4 distinct clusters i.e. Cluster A, B, C and D comprising of 5 inbred lines each (Fig.1).

Inbreds in cluster $A$ were further grouped into two subclusters viz; $A-1$ and $A-2$. Subcluster A-1 comprised of three maize inbred lines namely TSK-7, TSK-14 and TSK-16. In subcluster A-1, the maximum similarity coefficient occurred (0.72) between TSK-7 vs TSK-14 and the minimum similarity coefficient (0.61) occurred between TSK-7 vs TSK-16. Subcluster A-2 consisted of only 2 maize inbred lines namely TSK-41 and TSK43 , which showed the similarity coefficient value of 0.69 . Cluster B consisted of five maize inbred lines namely CIM-104, CIM-127, CIM-130, CIM-7242-67 and CIM-7242-149. In this cluster, the maximum (0.74) similarity coefficient was observed between CIM-127 vs CIM-130 and the minimum similarity coefficient (0.61) was found between CIM-104 vs CIM-7242-149 and CIM130 vs CIM-7242-149. Inbreds in cluster $C$ were grouped into two subclusters viz; C-1 and C-2. Subcluster C-1 consisted of three maize inbred lines namely TSK-9, TSK-11 and TSK-45. In Subcluster C-1, the maximum similarity coefficient $(0.70)$ was observed between TSK-11 vs TSK-45 and the minimum similarity coefficient (0.62) occurred between TSK-9 vs TSK-11. Subcluster C-2 consisted of only two inbreds namely TSK-2 and TSK-34, which showed the similarity coefficient value of 0.60 . Cluster D's inbreds were grouped into two subclusters viz., D-1 and D-2. Subcluster D-1 consisted of only two maize inbred lines namely TSK-48 and TSK-49, which showed the similarity coefficient value of 0.69 . Subcluster $D-2$ consisted of three maize inbred lines namely TSK-33, TSK-36 and TSK-39. In subcluster D-2, the maximum similarity coefficient $(0.73)$ occurred between TSK-36 vs TSK-39 and the minimum similarity coefficient $(0.66)$ occurred between TSK-33 vs TSK-39. SSR markers have been used to investigate genetic diversity and relationships several important crops like maize (Senior et al., 1998), rice (Saini et al., 2004), wheat (Plaschke et al., 1995), soybean (Rongwen et al., 1995) and rice bean (Muthusamy et al., 2008). Identifying genetic subpopulations provides key insight into a sample's ecology and evolution (Bryc et al., 2010; Glover et al., 2012; Moore et al., 2014), reveals ethnic variation in disease phenotypes (MorenoEstrada et al., 2014), and reduces spurious correlations in genome-wide association studies (Galanter et al., 2012; Behr et al. 2016).

SSR markers have been increasingly used as efficient tools to determine genetic diversity and relationship among maize inbred lines. In addition, SSR markers used in this study were highly polymorphic and revealed differences in maize inbred lines. The presence of high level of diversity among the inbred lines as deciphered by SSR markers indicated their suitability for breeding purposes.

\section{Acknowledgment}

We gratefully acknowledge Dr. H.C. Singh, Maize Breeder, Department of Genetics and Plant Breeding, CSAUAT, Kanpur (UP), India for providing the seed material and experimental field for this research work.

\section{References}

Barcaccia, G., L. Pallottini, P. Parrini and M. Lucchin: A genetic linkage map of a flint maize (Zea mays var. Indurata L.) Italian landraces using one way pseudo-test cross strategy and multilocus PCR based markers. Maydica, 51, 469-480 (2006).

Behr, A.A., K.Z. Liu, G.L. Fang, P. Nakka and S. Ramachandran: Fast analysis and visualization of latent clusters in population genetic data. Bioinformatics, 32, 2817-2823 (2016).

Bryc, K., A. Auton, M.R. Nelson, J.R. Oksenberg, S.L. Hauser, S. Williams, A. Froment, J.M. Bodo, C. Wambebe, S.A. Tishkoff, and C.D. Bustamante: Genome-wide patterns of population structure and admixture in West Africans and African Americans. Proceedings of the National Academy of Sciences of the United States of America, 107, pp. 786-791 (2010).

Cömertpay, G., F.S. Baloch, B. Kilian, A.C. Ülger and H. Özkan: Diversity assessment of Turkish maize landraces based on fluorescent labelled SSR markers. Plant Mol. Bio. Reporter, 30, 261-274 (2012).

Doyle, J.J. and J.L. Doyle: A rapid DNA isolation procedure for small quantities of fresh leaf tissue. Phytochemical Bulletin, 19, 11-15 (1987).

Galanter, J.M., J.C. Fernandez-Lopez, C.R. Gignoux, J. BarnholtzSloan, C. Fernandez-Rozadilla, M. Via, A. Hidalgo-Miranda, A.V. Contreras, L.U. Figueroa, P. Raska, G. Jimenez-Sanchez, I.S. Zolezzi, M. Torres, C.R. Ponte, Y. Ruiz, A. Salas, E. Nguyen, C. Eng, L. Borjas, W. Zabala, G. Barreto, F.R. González, A. Ibarra, P. Taboada, L. Porras, F. Moreno, A. Bigham, G. Gutierrez, T. Brutsaert, F. León-Velarde, L.G. Moore, E. Vargas, M. Cruz, J. Escobedo, J. Rodriguez-Santana, W. Rodriguez-Cintrón, R. Chapela, J.G. Ford, C. Bustamante, D. Seminara, M. Shriver, E. Ziv, E.G. Burchard, R. Haile, E. Parra and A. Carracedo: Development of a panel of genome-wide ancestry informative markers to study admixture throughout the Americas. PLOS Genet., 8, e1002554 (2012).

Glover, K.A., M. Quintela, V. Wennevik, F. Besnier, A.G.E. Sorvik and O.Y. Skaala: Three decades of farmed escapees in the wild: A spatio-temporal analysis of atlantic salmon population genetic structure throughout norway. PLOS ONE, 7, e43129 (2012).

Gupta, M., Y.S. Chyi, J. Romero-Severson and J.L. Owen: Amplification of DNA markers from evolutionarily diverse genomes using single primers of simple sequence repeats. Theor. Appl. Genet., 89, 998-1006 (1994).

Hidalgo, K.V.P., K.P. Mendez-Marroquin, E.V. Alvarez, J. ChavezOntiveros, P. Sanchez-Pena, J.A. Garzontiznado, M.O. VegaGarcia and J.A. Lopez-Valenzuela: Microsatellite-based genetic diversity among accessions of maize landraces from Sinaloa in Mexico. Hereditas, 150, 53-59 (2013).

Ignjatovic-Micic, D., D. Ristic, V. Babic, V. Andjelkovic, K. Markovic and J. Vancetovic: Genetic assessment of maize landraces from former Yugoslavia. Genetika, 45, 405-417 (2013).

Jaccard, P.: Nouvelles recherches sur la distribution florale. Bull. Soc. 
Vaud. Sci. Nat., 44, 223-270(1908).

Jambrovic, A., D. Šimic, T. Ledencan, Z. Zdunic and I. Brkic: Genetic diversity among maize (Zea mays, L.) inbred lines in Eastern Croatia. Period. Bio., 110, 251-255 (2008).

Liu, K., M. Goodman, S. Muse, J.S. Smith, E. Buckler and J. Doebley: Genetic structure and diversity among maize inbred lines as inferred from DNA microsatellites. Genetics, 165, 2117-2128 (2003).

Lu, H. and R. Bernardo: Molecular markers diversity among current and historical maize inbreds. Theor. Appl. Genet., 100, 552-556 (2001).

Molin, D., C.J. Coelho, D.S. Mximo, F.S. Ferreira, J.R. Gardingo and R.R. Matiello: Genetic diversity in the germplasm of tropical maize landraces determined using molecular markers. Genet. Mol. Res., 12, 99-114 (2013).

Moore, A.J., W.L. Moore, and B.G. Baldwin: Genetic and ecotypic differentiation in a californian plant polyploid complex (Grindelia, Asteraceae). PLOS ONE, 9, e95656 (2014).

Moreno-Estrada, A., C.R. Gignoux, J.C. Fernández-López, F. Zakharia, M. Sikora, A.V. Contreras, V. Acuña Alonzo, K. Sandoval, C. Eng, S. Romero-Hidalgo, P. Ortiz-Tello, V. Robles, E.E. Kenny, I. Nuño Arana, R. Barquera-Lozano, G. Macín-Pérez, J. GranadosArriola, S. Huntsman, J.M. Galanter, M. Via, J.G. Ford, R. Chapela, W. Rodriguez-Cintron, J.R. Rodríguez-Santana, I. Romieu, J.J. Sienra-Monge, B. del Rio Navarro, S.J. London, A. Ruiz-Linares, R. Garcia-Herrera, K. Estrada, A. Hidalgo-Miranda, G. JimenezSanchez, A. Carnevale, X. Soberón, S. Canizales-Quinteros, H. Rangel-Villalobos, I. Silva-Zolezzi, E.G. Burchard, and C.D. Bustamante: The genetics of Mexico recapitulates Native American substructure and affects biomedical traits. Science, $\mathbf{3 4 4}$, 1280-1285 (2014).

Muthusamy, S., S. Kanagarajan and S. Ponnusamy: Efficiency of RAPD and ISSR markers system in accessing genetic variation of rice bean (Vigna umbellata) landraces. Elec. J. Biotec., 11, 8 (2008).

NikolićA, D., D. Ignjatović-Micić, Z. Kovačević, M. Čamdžija, S. Filipović, and Mladenović Drinić: Genetic diversity of maize inbred lines as inferredfrom SSR markers. Genetika, 47, 489-498 (2015).

Plaschke, J., M.W. Ganal and M.S. Roder: Detection of genetic diversity in closely related bread wheat using microsatellite markers. Theor. Appl. Genet., 91, 1001-1007 (1995).

Rohlf, F.J.: NYSYS-pc: numerical taxonomy and multivariate analysis system, version 2.1. Setauket: Exeter Publications (2000).

Rongwen, J., M.S. Akkaya, A.A. Bhagwat, U. Lavi and P.B. Cregan: The use of microsatellite DNA markers for soybean genotype identification. Theor. Appl. Genet., 90, 43-48 (1995).

Sa, K.J., J.Y. Park, K.C. Park and J.K. Lee:Analysis of genetic mapping in a waxy/dent maize RIL population using SSR and SNP markers. Genes and Genomics, 34, 157 (2012).

Saini, A., K.S. Reddy and N. Jawali: Evaluation of long primers for APPCR analysis of mungbean [Vigna radiata (L.) Wilczek]: Genetic relationship and fingerprinting of some genotypes. Indian J. Biotechnol., 3, 511-518 (2004).

Salami, H.A., K.C. Sika, W. Padonou, D. Aly, C. Yallou, A. Adjanohoun, S. Kotchoni and L. Baba-Moussa: Genetic diversity of maize accessions (Zea mays L.) cultivated from benin using microsatellites markers. Amer. Jour. of Mol. Bio., 6, 12-24 (2016).

Senior, M.L., J.P. Murphy, M.M. Goodman and C.W. Stuber: Utility of SSRs for determining genetic similarities and relationships in maize using an agarose gel system. Crop Sci., 38, 1088-1098 (1998).

Sharma, L., B.M. Prasanna and B. Ramesh: Phenotypic and microsatellite-based diversity and population genetic structure of maize landraces in India, especially from the North East Himalayan region. Genetica, 138, 619-631 (2010).

Shehata, A.I., H.A. Al-Ghethar and A.A. Al-Homaidan: Application of simple sequence repeat (SSR) markers for molecular diversity and heterozygosity analysis in maize inbred lines. Saudi J. Biol. Sci., 16, 57-62 (2009).

Shehata, A.I., H.A. Al-Ghethar and A.A. Al-Homaidan: Application of simple sequence repeat (SSR) markers for molecular diversity and heterozygosity analysis in maize inbred lines. Saudi J. Biol. Sci., 16, 57-62 (2009).

Sneath, P.H.A. and R.R. Sokal: Numerical taxonomy. W.H. Freeman \& Co., San Francisco (1973).

Suteum, D., I. Bacila, V. Has, I. Has and M. Miclaus: Correction: Romanian Maize (Zea mays) Inbred Lines as a Source of Genetic Diversity in SE Europe, and Their Potential in Future Breeding Efforts. PLOS ONE, 9, 10 (2014).

Warburton, M.L., X.C. Xia, J. Crossa, J. Franco, A.E. Melchinger, M. Frisch, M. Bohn and D. Hoisington: Genetic characterization of CIMMYT inbred maize lines and open-pollinated populations using largescale fingerprinting methods. Crop Sci., 42, 1832-1840 (2002).

Weir, B.S.: Genetic data analysis II. $2^{\text {nd }}$ Edn., Sinaeur Associates Inc., Sunderland, MA. p. 445 (1996).

Zheng, H., H. Wang, H. Yang, J. Wu, B. Shi, R. Cai, Y. Xu, A. Wu and L. Luo: Genetic diversity and molecular evolution of Chinese waxy maize germplasm. PLoS ONE, 8, e66606 (2013). 